\title{
Konferencja „Język trzeciego tysiąclecia” XI: „Język w przestrzeni semiotyki społecznej" zorganizowana przez Krakowskie Towarzystwo Popularyzowania Wiedzy o Komunikacji Językowej „Tertium”, Kraków (konferencja zdalna), 2-4 grudnia 2020 (sprawozdanie)
}

DOI: http://dx.doi.org/10.12775/RP.2021.017

W dniach 2-4 grudnia 2020 roku w ramach cyklu „Język trzeciego tysiąclecia” odbyła się konferencja naukowa pt. „Język w przestrzeni semiotyki społecznej”. Organizatorem grudniowego spotkania naukowego integrującego międzynarodowe środowisko językoznawcze było Krakowskie Towarzystwo Popularyzowania Wiedzy o Komunikacji Językowej „Tertium”. Wydarzenie zaplanowano pierwotnie na początek roku, lecz formuła musiała ulec zmianie ze względu na sytuację epidemiczną. Ubiegłoroczna jedenasta edycja była spotkaniem wyjątkowym zarówno ze względu na międzynarodowy charakter obrad, w których wzięło udział sześćdziesięcioro sześcioro językoznawców reprezentujących ośrodki naukowe w Polsce, Niemczech, Szwecji, Grecji, Rosji, Czechach, Kosowie oraz Nigerii, jak i ze względu na sposób przeprowadzenia - spotkanie odbyło się w trybie zdalnym przy użyciu aplikacji Zoom. Konferencja była okazją do wymiany myśli w dwóch językach, polskim oraz angielskim. Dodatkową atrakcją przygotowaną dla uczestników był konkurs wiedzy o Krakowie, w którym do wygrania były trzy vouchery do krakowskich restauracji sponsorowane przez Urząd Miasta Krakowa.

Konferencja rozpoczęła się 2 grudnia 2020 roku. Uczestników powitali w języku polskim i angielskim przewodniczący Zarządu Krakowskiego Towarzystwa Popularyzowania Wiedzy o Komunikacji Językowej „Tertium”: Władysław Chłopicki, Jadwiga Kita-Huber oraz Andrzej Kuropatnicki.

Zaproszenie do wygłoszenia wykładów plenarnych przyjęli profesorowie Michał Krzyżanowski z Uniwersytetu w Uppsali, Zoltán Kövecses z Uniwerstytetu Loránda Eötvösa oraz Konrad Dominas z Uniwersytetu im. Adama Mickiewicza w Poznaniu. Pierwsze wystąpienie dotyczyło prawicowego populizmu w narodowym i ponadnarodowym dyskursie politycznym. Wy- 
kłady plenarne otwierające obrady drugiego i trzeciego dnia konferencji poświęcone były zagadnieniom związanym $\mathrm{z}$ teorią rozwiniętej metafory konceptualnej oraz człowiekowi jako podmiotowi uwikłanemu w sieci algorytmów i mechanizmów współczesnych mediów.

Konferencja odbywała się $\mathrm{w}$ trzech równoległych sekcjach. $\mathrm{W}$ trakcie trzydniowego spotkania przeprowadzono obrady łącznie w siedemnastu panelach poświęconych elementom humorystycznym w języku, problematyce przekładu oraz aspektom pragmatycznym języka. Uczestnicy skupili się na analizie humorystycznych gier językowych w dowcipach, paskach tytułujących wiadomości, komediach kryminalnych oraz $\mathrm{w}$ dyskursie politycznym i medialnym. Ponadto referenci omówili mechanizmy dyskursywno-pragmatyczne odmowy, zagadnienia z pragmatyki antropologicznej oraz odwołali się do emocji w komentarzach internautów. Istotnymi zagadnieniami z perspektywy przekładowej były tłumaczenia symultaniczne, audiowizualne i ustne. Rozważania teoretyczne dotyczyły m.in. kulturotwórczej roli przekładu, kulturemów w tłumaczeniu strategicznym i transferu kulturowego. Ze względu na tematykę podejmowaną w „Roczniku” uwagę skierujemy na wystąpienia o tematyce przekładoznawczej, której poświęcono sześć z siedemnastu paneli.

Obrady w ramach pierwszego panelu dotyczyły przede wszystkim kulturowych uwarunkowań tłumaczenia i wszelkich punktów trudnych czy ewentualnych konfliktów na tym tle. Mikhail Ilyin przedstawił różne konteksty tłumaczenia kluczowych pojęć Maxa Webera na język angielski i rosyjski. Na ich przykładzie zaprezentował on silne i słabe strony możliwych rozwiązań translatorskich oscylujących między dwoma ekstremami - tworzeniem pojęć całkowicie nowych na gruncie języka docelowego i wykorzystaniem zasobów języka docelowego do nadania nowej treści zgodnie z ich zakresem semantycznym w tekście wyjściowym. W kolejnym referacie Caterina Squillace zanalizowała proces tłumaczenia semiotycznej wielogłosowości na podstawie włoskich i polskich przekładów Mistrza i Małgorzaty Bułhakowa, tekstu szczególnie wyróżniającego się swą polifonicznością i wielowarstwowością. Prelegentka przedstawiła i omówiła szereg miejsc wymagających od tłumacza szczególnej inwencji i zaprezentowała rozwiązania translatorskie zastosowane w odnośnych fragmentach. Przeanalizowała także kulturowe aspekty przekładu ujawniające się dość wyraźnie w bliższym kulturze tekstu wyjściowego kręgu polskim i oddalonym odeń kręgu włoskim, wymagającym od tłumacza użycia innych strategii. Aspekty kulturowe wybrzmiały 
jeszcze silniej w referacie Arkadiusza Jabłońskiego na temat wybranych aspektów dotyczących stereotypów i związanych z nimi nieporozumień komunikacyjnych, nierzadkich w kontakcie z kulturą japońską. W ostatnim referacie tego panelu Grzegorz Grzegorczyk zajął się problematyką interakcji w komunikacji między coachem a jego klientem. Autor posłużył się narzędziami analizy mikrogenetycznej w celu jakościowego ujęcia procesu komunikacji i zbadania kluczowych momentów, do których dochodzi w tym kontakcie.

Drugi dzień obrad podzielono na dwie sesje: ranną i popołudniową. W ramach porannego bloku obrad, któremu przewodniczyła Agata Hołobut, przedstawiono cztery referaty. Pierwszy z nich autorstwa Elżbiety Tabakowskiej dotyczył tłumaczenia na język polski anglojęzycznej książki Ireny Powell The Daughter Who Sold Her Mother. Omawiając istotny z perspektywy przekładoznawczej aspekt historyczny, kulturowy i społeczny, autorka podkreśliła wagę krytycznej analizy dyskursu jako elementu warsztatu tłumacza oraz wskazała na niebezpieczeństwa zniekształcania wymowy tłumaczonego tekstu. Kulturotwórcza rola przekładu przedstawiona została na podstawie działalności translatorskiej Panajotisa Kondylisa, jednego z najwybitniejszych intelektualistów drugiej połowy XX wieku i autora tłumaczeń klasycznych dzieł dawnej i współczesnej humanistyki na język grecki. Filip Olkiewicz zwrócił szczególną uwagę na terminologię specjalistyczną przyjmowaną w tłumaczeniu oraz styl i charakter zastosowanego w nim języka. Interesującą tematykę z perspektywy językoznawczej i społecznej podjęła Marta Chojnacka-Kuraś. Swój odczyt poświęciła analizie językowej książek edukacyjnych na temat choroby nowotworowej, adresowanych do pacjentów i ich rodzin: Oskarżony rak. Śledztwo kryminalne oraz Co to ten rak?. Punktem wyjścia przedstawionych rozważań była teoria metafory konceptualnej George'a Lakoffa i Marka Johnsona oraz teoria integracji pojęciowej Gillesa Fauconniera i Marka Turnera. Referentka zauważyła, że mimo próby odnalezienia nowych form wyrazu autorzy książek wykorzystali skonwencjonalizowaną metaforę przeciwnika. Obrady w sekcji zakończyło krytyczne omówienie werbalnych i wizualnych reprezentacji kulinarnych w filmach Ramen. Smak wspomnień, Kwiat wiśni i czerwona fasola oraz Smak curry. Maria Mocarz-Kleindienst wskazała na istotę jakości przekładu realiów kulturowych jako elementów przekazu treści kulturowych.

Po przerwie obiadowej, podczas której z uwagi na zdalny charakter konferencji nie doszło do typowych dla tradycyjnych konferencji rozmów 
kuluarowych, rozpoczął się trzeci panel przekładowy. Maria Piotrowska odniosła się do procesu decyzyjnego, do którego dochodzi w trakcie tłumaczenia na język angielski kryminałów autorstwa duetu ukrywającego się pod pseudonimem Maryla Szymiczkowa. Istotą prezentacji było studium zaistniałych i możliwych luk pragmatycznych w zakresie kulturemów, mogących powodować zaburzenia w komunikacji międzykulturowej. Kolejny referat poświęcono zagadnieniu eksplicytacji i temu, jak zmienia ona tekst. Ewa Gumul oddała tutaj głos tłumaczom ustnym specjalizującym się w tłumaczeniu symultanicznym w celu zrozumienia tego, jak postrzegają oni swoją rolę w tym obszarze. Cennym wyróżnikiem badań przeprowadzonych przez autorkę była ich wieloaspektowość - zestawiła ona analizę produktu, jakim jest przekład, $\mathrm{z}$ analizą samego procesu tłumaczenia, tak jak prezentuje się on na podstawie protokołów retrospektywnych. Marcin Walczyński naświetlił w swoim wystąpieniu problematykę psychologii tłumacza ustnego, dokonując charakterystyki zarówno nurtu kognitywnego, jak i psycho-afektywnego, by potem na przykładzie badań przeprowadzonych wśród siedemdziesięciorga sześciorga tłumaczy przysięgłych języka angielskiego (tłumaczących konsekutywnie) poddać analizie czynniki psycho-afektywne i ich oddziaływanie na proces tłumaczenia. Panel zakończyła prezentacja Anety Tatarczuk na temat serialu 1983 - produkcji umieszczonej w polskich realiach, ale powstałej w języku angielskim i tłumaczonej następnie na polszczyznę. Niewolnicze trzymanie się wierności wobec języka wyjściowego $\mathrm{w}$ wielu przypadkach nie wpłynęło pozytywnie na naturalność wypowiedzi postaci pojawiających się na ekranie. Nasuwa się tutaj pytanie, czy wierność jest ważniejsza od naturalności odczuwanej przez widza w języku docelowym.

Czwarty panel przekładowy stanowił kontynuację wątków poruszanych na obradach w poprzedniej grupie i dotykał materii przekładu audiowizualnego. Agata Hołobut dokonała analizy audiodeskrypcji w perspektywie przekładoznawczej, przedstawiając ją jako przykład przekładu intersemiotycznego. W takim ujęciu audiodeskryptor jawi się nie tyle jako osoba opisująca to, co dzieje się na ekranie, ile jako medium odzwierciedlające pracę kamery i stosowany montaż. W ostatnim tego dnia referacie Agnieszka Seweryn przyjrzała się dziełu rosyjskiego dramaturga Iwana Wyrypajewa pt. Tlen, a dokładnie jego adaptacji w formie albumu wizualnego. Autorka poddała analizie trudności pojawiające się w tłumaczeniu (napisy) tego utworu składającego się z dziesięciu teledysków stylizowanych na współ- 
czesne, w których Wyrypajew wykorzystuje konwencje typowe dla teatru, filmu dokumentalnego czy innych form.

W ramach piątkowego panelu poświęconego problematyce przekładu podjęto rozważania na temat tłumaczenia specjalistycznego. Referatem otwierającym obrady ostatniego dnia konferencji były różnice pojęciowe w polskim i anglosaskim prawie karnym. Posługując się takimi przykładami jak homicide - zabójstwo, assault - czynna napaść i burglary - włamanie, Jan Gościński zauważył, że anglosaski termin assault ulega transformacji znaczeniowej, ponieważ w USA w wielu stanach odnosił się wcześniej do gróźb lub usiłowania uszkodzenia ciała, a samą ich realizację określano terminem battery. Izabela Bawej omówiła wybrane aspekty przekładu prawniczego w kontekście międzykulturowym na przykładzie postępowania ekstradycyjnego między Republiką Federalną Niemiec a Rzeczpospolitą Polską. Magdalena Łomzik przedstawiła następnie analizę dotyczącą tłumaczenia dokumentacji medycznej jako inicjatywy społecznej. W toku rozważań zaprezentowała trzy narzędzia praktyczne z perspektywy tłumacza języka niemieckiego, takie jak translator nazw zgodnych z klasyfikacją nazw ICD-10, internetowy leksykon medyczny oraz tłumaczenia fragmentów dokumentacji medycznej, wykonywane przez studentów medycyny i dostępne pod adresami washabich.de, befunddolmetscher.de, weisse-liste.de. Ostatni referat panelu poświęcony był transkreacji w przekładzie melicznym. Olga Mastela zaprezentowała na przykładzie twórczości Wojciecha Młynarskiego kunszt i strategie stosowane przez tego autora, który spolszczając francuskojęzyczne piosenki, w wielu przypadkach musiał niejako tworzyć je na nowo, odkrywając tym samym inne sensy i aluzje niż te zawarte w tekstach wyjściowych. Analiza oparta była na ujęciu transkreacji według Harolda de Camposa.

$\mathrm{W}$ ostatnim panelu przewidziano dwa wystąpienia. W pierwszym $\mathrm{z}$ nich Szymon Kukulak przedstawił specyfikę przekładów tekstów fantastycznych, szczególnie uwzględniając oceny odbiorców oraz proces ich kształtowania. $\mathrm{Na}$ przykładzie długich serii wydawniczych zaprezentował on ewolucję recepcji niektórych rozwiązań translatorskich, które potrafią się przyjąć w gronie odbiorców tego typu literatury. W ostatnim referacie przewidzianym na tę konferencję Ewa Konefał dokonała autorskiego przeglądu historii rosyjskojęzycznej refleksji dotyczącej badań kulturowych w przekładzie. Jak przekonywała, zainteresowanie aspektami kulturowymi należy datować na okres jeszcze sprzed tzw. zwrotu kulturowego w przekładoznawstwie i ujmować możliwie szeroko. Badania nad przekładem prowadzone są bo- 
wiem z różnych pozycji metodologicznych i obejmują wiele specjalności. To wystąpienie zakończyło ostatni panel poświęcony przekładowi.

Nie będzie przesadą stwierdzenie, że obrady były niezwykle różnorodne i bogate w treść - dość powiedzieć, że przedstawiliśmy tylko jedną trzecią wszystkich wystąpień, ograniczając się jedynie do sekcji przekładoznawczych. Zdalna forma spotkań miała tę niewątpliwą zaletę, że goście z ośrodków zagranicznych mogli uczestniczyć w konferencji, unikając uciążliwości podróżowania $\mathrm{w}$ dobie pandemii. Z niemałym zaskoczeniem przyjęliśmy, że twórcza i pogłębiona dyskusja jest możliwa również „na łączach”, choć oczywiście jest ona wówczas bardziej zorganizowana i trochę mniej spontaniczna. Wielkim nieobecnym i oczywistą największą wadą był brak kontaktu osobistego i możliwości spotkania twarzą w twarz, ale nie można za to winić organizatorów, gdyż pandemia ma swoje ograniczenia. Kolejna konferencja planowana jest już na przyszły rok i z niecierpliwością czekamy na to, co tym razem przygotuje Krakowskie Towarzystwo Popularyzowania Wiedzy o Komunikacji Językowej „Tertium”.

Filip Olkiewicz olkiewicz.filip@doktorant.umk.pl ORCID: 0000-0002-1364-7781 (Uniwersytet Mikołaja Kopernika w Toruniu)

Emilia Pankanin pankanine@umk.pl ORCID: 0000-0002-0718-5138 (Uniwersytet Mikołaja Kopernika w Toruniu) 